\title{
Yeni Kurumsalcı Perspektiften Hindistan Siyasetinin Değişimi $^{1}$
}

\author{
DOI: 10.26466/opus.796323
}

\section{Hayati Ünlü*}

* Dr. Öğretim Üyesi, Şırnak Üniversitesi, İktisadi ve İdari Bilimler Fakültesi, Siyaset Bilimi ve Kamu Yönetimi Bölümü, Şırnak/Türkiye

Öz

E-Posta: unluhayati@gmail.com

ORCID: $\underline{0000-0002-2645-5930}$

Bu makalenin amacl, Hindistan siyasetinin değişimini kurumsal analiz üzerinden incelemektir. Kurumlar son dönemlerde siyasal değişim çalışmalarında fazlasıyla incelenmektedir. Sadece resmi kurumlar değil, gayri resmi kurumlar üzerinden de ülke siyasetlerinin değişimi analiz edilebilmektedir. Bu makalede de Hindistan siyaseti, yükselen gayri resmi kurumlar üzerinden incelenecektir. Hindistan siyasetindeki değişim, gayri resmi kurumların değişimi üzerinden tartışılacaktır. Hindistan'ın bağımsızlı̆̆ı sonrası ülkede iktidar olan Kongre Partisi ülkedeki hem ulus hem de devlet inşası süreçlerini yöneten aktör olmuştur. Resmi kurumlar, Kongre Partisi'nin yönetme gücünü arttırmışken; gayri resmi kurumlar da yönetme kapasitesini pozitif yönde etkilemiştir. Bu noktada Kongre Partisi'nin başvurduğu gayri resmi kurum sekülerizm olmuştur. Sekülerizm, çeşitlilikleriyle tanınan ülkenin bir arada yaşama kültürünü güçlendirmiştir. Kongre Sistemi'nin çöküşü sonrası ise yükselen Hindu milliyetçiliği sekülerizmin yerini almıştır. Hindutva olarak bilinen Hindu milliyetçiliği ideolojisi, bir gayri resmi kurum olarak hem kitleleri mobilize etmiş hem de BJP'yi iktidara taşımıştır. Hindu milliyetçiliğinin anti-demokratik ve dışlayıcı karakteri ise hem ulusal hem de bölgesel anlamda Hindutva karşıtı bir dalga ortaya çıkarmıştır. Bu bağlamda Hindutva'ya alternatif birçok ulusal ve bölgesel gayri resmi kurum yükselişe geçmiştir. Çalışmada tüm bu gayri resmi kurumların yükselişi ve Hindistan siyasetine etkisi ele alınacaktır.

Anahtar Kelimeler: değişim, hindistan, kurumlar, gayri resmi kurumlar, partiler.

\footnotetext{
${ }^{1}$ Bu çalışma Hindistan'da Hakim Parti Sisteminin Değişimi: Kurumsalcı Bir Analiz adlı doktora tezinden yararlanılarak hazırlanmıştır.
} 


\title{
The Change of Indian Politics from a New Institutionalist Perspective
}

\begin{abstract}
The purpose of this article is to examine the change in Indian politics through institutional analysis. In the recent period, institutions have been studied extensively in political change studies. The change in country policies has been able to analyze not only through official institutions but also through informal institutions. This article will also examine Indian politics through emerging informal institutions. The change in Indian politics will be discussed through the change of informal institutions. The Congress Party, which was in power in the country after the independence of India, became the actor that managed both nation and state building processes in the country. While formal institutions increased the power of the Congress Party in those years; informal institutions also positively affected the capacity to manage in the same years. At this point, the unofficial institution that the Congress Party applied to was secularism. During the Congress rule, secularism strengthened the coexistence culture of the country, which was known for its diversity. After the collapse of the Congress System, the rising Hindu nationalism replaced secularism. The ideology of Hindu nationalism known as Hindutva, as an unofficial institution, has both mobilized the masses and brought the BJP to power. The anti-democratic and exclusionary character of Hindu nationalism has created an anti-Hindutva wave both nationally and regionally. In this context, many alternative national and regional informal institutions to Hindutva have been on the rise. The rise of all these unofficial institutions and their impact on Indian politics will be discussed in the study.
\end{abstract}

Keywords: change, india, institutions, informal institutions, parties. 


\section{Giriş}

Küresel siyaset, Karl Polanyi (2001)'ninbelirttiği gibi büyük bir dönüşüm sürecinden geçmektedir. Nasıl eski küresel düzen Çin, Hindistan gibi yükselen güçlerin yeni davranışlarıyla eskisi gibi kalamıyorsa, ülkelerin iç siyasetleri de ekonomik krizlerden sağlık krizlerine, jeopolitik çatışmalardan küresel göç hareketlerine kadar birbirinden farklı birçok gelişmeyle değişime maruz kalmaktadır. Kovid-19 salgını da bu değişimin hızını arttırmışken; iç siyasetlerde önceki dönemlere göre daha masif bir şekilde toplumsal talepler yükselmektedir. Bazen ekonomik, bazen gıda, bazen güvenlik, bazen de eğitim gibi konularda tabandan yükselen talepler, devletlerin kapasiteleri üzerinden cevap verebilme yeteneklerini test etmekte, kimi zaman da iç siyasal istikrara zarar verebilmekte ve kurumsal çürüme tartışmalarını alevlendirebilmektedir. Özellikle içerde herhangi bir karışıklık, kargaşa ve düzensizlik arzu etmeyen devletlerin aklı ise hemen kuralların düzenleyici rolüne başvurabilmektedir. Kuralların daha organize ve güçlü bir şekilde geri dönüşü, davranışlara yön verebilmesi ve dolayısıyla belli bir sonucun hedeflenmesi ise kurumları tartışmanın merkezine getirmektedir. Kurumlar bu bağlamda karar vericiler için belirsizlik çağında kitle mobilizasyonları gibi istikrar, düzen ve öngörülebilirliğe tehdit olabilecek tüm oluşumlar için bir veto oyuncusu olarak işlev görebilmektedir (Lowndes ve Roberts, 2013, s.1-16).

Kurumların bu düzenleyici işlevlerine ek olarak, son dönemlerde kurumsalcı düşünürler en az resmi kurumlar kadar gayri resmi kurumların da önemle altını çizmişlerdir. Yeni kurumsalcılığın ikinci dalgasına karşılık gelen bu düşünürlere göre, siyaset ve yönetişim yalnızca resmi kurallarla değil, aynı zamanda gayri resmi kurallar, normlar ve değerlerle de belirlenebilmektedir. Bu bağlamda, gayri resmi kurumlar, tıpkı resmi kurumlar gibi, kurallar koyan, davranışları şekillendiren ve sonucu etkileyen araçlar olarak ortaya çıkabilmektedir. Başka bir deyişle, gayri resmi kurumlar da oyunun kurallarını değiştirebilmektedir. Bu açıdan gayri resmi kurumların kapasiteleri, bu küresel ve yerel sosyo-politik dönüşüm çağında değişimi yönetmek için kullanılabilir. Ayrıca gayri resmi kurumlar yalnızca adetler, gelenekler, kültürel ve bölgesel alışkanlıklar olarak ortaya çıkmaz; aynı zamanda bir fikir ve ideoloji olarak da yükselebilir (Helmke ve Levitsky, 2004, s.725-734). Nitekim bu çalışmada da Hindistan siyasetinin dönüşümü bazen 
bir fikir ve ideoloji bazen de kültürel özellikler üzerinden yükselen gayri resmi kurumlar arası devam eden hegemonik mücadele üzerinden incelenecektir.

Bağımsızlı̆̆ını 1947 yılında ilan etmiş olan Hindistan'da uzun yıllar iktidar, bir hâkim parti karakterine sahip olan Hindistan Kongre Partisi'nin elinde bulunmuştur. İngiliz sömürgeciliğine karşı bir bağımsızlık hareketi olarak ortaya çıkan Hindistan Ulusal Kongresi, bağımsızlık sonrası kendisini siyasal bir partiye dönüştürmüş ve bağımsızlığın kazanılmasında en önde gelen aktör olarak da hem yeni millet ve devlet inşasını gerçekleştirmiş hem de kendi kurduğu sistemi kendisiyle özdeşleştirebilmiştir. Nitekim Rajni Kothari (1964) söz konusu hâkim parti dönemini Kongre Sistemi olarak isimlendirerek Kongre Partisi ve sistemin doğasının nasıl örtüştüğünün altını çizmiştir. Kongre Partisi bu dönemde kabul edilen yeni anayasadan devletin asli organlarına, hükümet sisteminden seçim sistemine kadar tüm resmi kurumları karizmatik lider Nehru liderliğinde belirleyerek iç politikada oyunun kurallarını kendisi belirlemiştir. Yine söz konusu resmi kurumlar aracılığıyla kast siyasetinin büyük önem arz ettiği ülke siyasetinde kurmuş olduğu patronaj ilişkileriyle uzun yıllar iktidarını konsolide edebilmiştir (Hankla, 2008, s.41-60). Nitekim Kongre Partisi'nin hâkim parti karakterini kaybedip iktidardan düştügü süreç için söz konusu kurumsal yapının çürümesiyle ilgili olduğu kabul gören güçlü argümanlardan biridir. Ancak bu analiz belki de konunun yarısını içermektedir ve gayri resmi kurumlar analizini ihmal etmektedir.

Kongre Partisi'nin hâkim parti sisteminin gücü şüphesiz resmi kurumlar aracılığıyla sağlanmıştır. Ancak gayri resmi kurumlar da en az resmi kurumlar kadar sistemin devamına katkı sağlamıştır. Bu açıdan kurulan patronaj ilişkilerinin ötesinde, sosyal yapıyı bir arada tutan ve kutuplaşmayı önleyen gayri resmi kurumların varlığı göz ardı edilmemelidir. Burada en büyük önem arz eden gayri resmi kurum ise sekülerizm fikridir. Seküler bir toplum inşasıyla Kongre Partisi, kimlik siyasetinin ülkede önüne geçebilmiş ve farklı çıkarlar arası rekabetin Kongre Partisi içerisinde yapılabilmesini sağlamıştır (Upadhyaya, 1992, s.815-853). Bu açıdan bir hâkim parti olarak Kongre Partisi hem bir sosyal hem de bir ideolojik koalisyon özelliği taşımıştır. Kongre Sistemi'nin çöküşü ise sekülerizm fikrinin çöküşüyle yakından ilgili olmuştur. Bir taraftan mevcut sekülerizm fikrinin yoğun eleştirilerle içini boşaltan Hindu milliyetçileri, diğer taraftan ona alternatif bir gayri 
resmi kurum olarak Hindutva'yı yüceltmeye çalışmışlardır (Sen, 1993, s.523). Bir fikir ve bir ideoloji olarak Hindutva, sadece Kongre Partisi'nin iktidardan düşürmemiş, aynı zamanda bugünkü BJP iktidarının de önünü açarak ülke siyasetinin değişimine büyük katkı sağlamıştır.

1970'lerden bu yana her geçen gün güçlenen Hindutva, özellikle 2014 sonrası Modi liderliğindeki BJP iktidarıyla birlikte hem yeni bir millet hem de yeni bir devlet inşası sürecinde iç politikada kuralları belirleyen, aktörlerin davranışlarını şekillendiren ve netice itibariyle sonuca etki eden bir gayri resmi kurum niteliği göstermiştir. Ancak gerek sekülerizmin moral ekonomik mirası gerekse de Hindutva'nın birçok sosyal kesimi ayrıştırıcı söylemi, alternatif çok sayıda rakip gayri resmi kurumun ortaya çıkışına aracılık etmiştir (Swaroop, 2017, s.52). Bugün Hindutva fikrine karşı, Güney ve Doğu Hindistan'da Keralite, Dravidanadu, Hilsa, Tamillik gibi bölgesel gayri resmi kurumlar ortaya çıkmaktayken; yine tarihten gücünü alıp Hindutva'nın belli kesimlerde etkileyiciliği kaybetmesini fırsat bilen sekülerizm ve Ambedkarizm gibi gayri resmi kurumlar da bir geri dönüş süreci yaşamaktadır. Sekülerizm sonrası Hindistan siyasetinin merkezine oturan ve siyaseti dönüştürmeyi başaran Hindutva'nın koltuğu ise bu rakip gayri resmi kurumlar tarafından sallanmaktadır ve hegemonik mücadele her geçen gün artmaktadır. Bu doğrultuda çalışmada öncelikle yükselen gayri resmi kurumlar literatürü incelenecek ve ardından Hindutva'nın nasıl sekülerizme karşı hegemonik üstünlüğe ulaşttğı süreç analiz edilecektir. Devamında Hindutva'nın dönüştürücü gücüne teslim olmak istemeyen rakip siyasilerin nasıl Hindutva karşıtı rakip gayri resmi kurumları inşa edip toplumu harekete geçirdikleri tartışlacaktır. Sonuç olarak da artık işlevlerini tam olarak göremeyen kurumların değişime gittiği örneğinden hareketle, Hindistan'daki gayri resmi kurumlar arası mücadelenin geleceğiyle ilgili tartışmada bulunulacaktır.

\section{Kurumların Artan Önemi ve Gayri-Resmi Kurumların Yükselişi}

Son yıllarda kurumsal analizler, karşılaştırmalı siyaset çalışmalarında merkezi bir odak haline gelmiştir. Özellikle gelişmekte olan dünyadaki kurumsal değişim dalgasından beslenen çeşitli araştırma geleneklerinden düşünürler, anayasal tasarım, seçim sistemleri ve diğer resmi kurumsal düzenlemelerin siyasi ve ekonomik sonuçları nasıl etkilediğini incelemişlerdir. Bu 
çalışmalar önemli teorik ilerlemeler sağlamışken, güncel siyaset yapımcıları için oldukça işlevsel olduğunu tartıştığımız kurumlar, tanımı itibariyle örgütlerle aynı manaya gelmemekle birlikte, sosyal, politik ve ekonomik ilişkileri düzenleyen resmi ve gayri resmi kurallar ve normlar olarak tanımlanmaktadır (North, 1990). İnsanlar ve siyaset tarafından hayata geçirilen kurumlarin (North, 1990; Leftwich ve Sen, 2010), neden bu kadar işlevsel olduğu oldukça tartışılmaktadır. Bu açıdan "oyunun kuralları" olarak görülen kurumlar, her şeyden önce toplumdaki fırsatların, varlıkların ve kaynakların dağılımın yapılandırmaktadırlar. Siyasal açıdan ise daha güçlü siyasi davranış ve sonuçları şekillendirmekte ya da kısıtlamaktadır. Örneğin, siyasi elitler, seçim süreçleri, anayasalar ve piyasa düzenlemeleri gibi siyasi ve ekonomik ilişkilerin yanı sıra gayri resmi güç ve kaynak paylaşımını (DFID, 2010, s. 22) yönetmek için resmi kuralları belirleyebilmektedirler. Bu şekilde, kurumlar hem güç ilişkileriyle şekillenebilmekte hem de kabul edilebilir yönetişim biçimleri ve iktidarın kullanılması için araçsallaştırılabilmektedirler (Wilson, 1997,s.17).

İktidar ilişkilerinde bu kadar büyük önem arz eden kurumların genel bazı özellikleri onların önemini ortaya koymak açısından kritiktir. Bu açıdan ilk olarak kurumların kural koyma özellikleri rasyonel davranış ve siyaset açısından oldukça önemlidir. Günlük sosyal, ekonomik ve politik yaşam için nispeten öngörülebilir bir yapı sağlamaktadırlar (North, 1990, s.6). Kurumlar içerisinde üretilen kural, norm ve değerler kurum içi aktör ve bileşenlerin teşviklerini ve nasıl bir davranış sergileyeceklerini belirlemektedir ki bu da kurumların ikinci özelliğine karşıllk gelmektedir. Yani kurumların ikinci özelliği, bünyesindeki üyeleri için belli davranış kalıpları üretebilmesiyle alakalıdır. Davranışlara yön verebilme derecesi kurumun bu noktada kalitesini ortaya koymaktadır. Ancak zamanla kalıcı davranış kalıplarına yol açabilen kurumların kendileri de değişebilmektedir. Bu noktada kurumsal değişim tartışmaları çerçevesinde ele alınan kurumlar, insanların eylemleri yoluyla sürekli olarak yenilenebilmektedir (Giddens, 1984). Böylece toplumların değişimi yapılandırılabilirken (North, 1990,s.3), kurumsallaşmış davranışları değiştirmek de zor olabilmektedir. Kurumların üçüncü özelliği ise siyasal sonuçları üretebilme ya da etkileyebilmeleriyle ilgilidir. Kurumlar oyunun kuralların belirleyip, davranışlara etki edebilmeleriyle arzu edilen sonuca ulaşmada teşvik edici bir rol oynayabilmektedirler. Tabi 
olumlu sonuç üreten kurumlar yola devam ederken; olumsuz sonuç üreten kurumlar ise değişime tabi tutulabilmektedir (Leftwich ve Sen, 2010).

Kurumlar çeşitleri itibariyle ise hem resmi hem de gayri resmi kurumlar olarak karşımıza çıkabilmektedirler. Resmi kurumlar, resmi makamlarca uygulanan yazılı anayasayı, kanunları, politikaları, hakları ve düzenlemeleri içermekteyken; gayri resmi kurumlar, düşünce ve davranışı şekillendiren, genellikle yazılı olmayan sosyal normlar, değerler veya geleneklerdir (Leftwich ve Sen, 2010; Berman, 2013). Pratik siyasette, resmi ve gayri resmi kurallar ve normlar birbirlerini tamamlayabildikleri gibi rekabet de edebilmekte ya da örtüşebilmektedirler (Jütting, Drechsler, Bartsch ve de Soysa, 2007, s.36; Leftwich ve Sen, 2010, s.17). Hangisinin daha güçlü veya zayıf olduğu ise bağlama bağlıdır (Unsworth, 2010). Bazı durumlarda gayri resmi kurumlar, resmi kurumların altını oyabilmekteyken; bazen de onların yerlerini alabilmektedirler (Leftwich ve Sen, 2010, s.17; Jütting,Drechsler, Bartsch ve de Soysa, 2007, s.35-36). Resmi olmayan sosyal normlar, genellikle resmi devlet kurumlarının dizaynını ve uygulanmasını şekillendirebilmektedir (Migdal, 2001; Jütting,Drechsler, Bartsch ve de Soysa, 2007, s.7).

Siyasi kurumlarla ilgili genel karşılaştırmalı araştırmalar, daha çok resmi kurum ve kurallara odaklanarak onlara öncelik verme ve gayri resmi kurumları siyasal açıdan elde edilmek istenen sonuçlara zararlı görme eğilimindedir (Unsworth, 2010). Ancak aynı zamanda kliyentalizmden nepotizme, kayırmacılıktan patrimonyalizme kadar birçok bağlamda değişen gayri resmi kurumların daha güçlü siyasi davranış ve sonuçları şekillendirebileceği de düşünülmektedir. Başka bir deyişle oyunun bu gayri resmi kurallarını dikkate almama durumu, politik davranışın altında yatan en önemli teşviklerin ve kısıtlamaların çoğunu gözden kaçırma riski ortaya çıkarabilecektir. Nitekim günümüz dünyasında fikirler gibi gayri resmi kurumlar, resmi güç olan iktidarlar tarafından güç ilişkilerinin kendileri lehine devam etmesi için kullanılabilmektedir. Bu açıdan bu çalışmadaki kurumsal analiz motivasyonu, iyi kurumsal analizin hem resmi hem de gayri resmi kurumlara titiz bir dikkat gerektirdiğinden dolayı, siyasi davranışları mümkün kılan ve sınırlayan teşvikleri anlamak adına gayri resmi kurumların da en az resmi kurumlar kadar dikkatli analiz edilmesi gerektiğiyle ilgilidir.

Gayri resmi kurumlar, karşılaştırmalı siyasette kurumsalcı literatürün sınırlarında kalmış olsa da, kurumlar açısından gayri resmiliğe olan ilgi hiç de 
yeni değildir. Bugüne kadar "Prizmatik toplumlar", "ahlaki ekonomi", "sevgi ekonomileri", "yasal çoğulculuk", "kayırmacılık", "yolsuzluk", Japonya'daki hükümet-iş dünyası ilişkileri üzerine yapılan çalışmalar ve Sovyetler Birliği ve ABD Senatolarının "halk kanunları" üzerine yapılan çalışmalar yazılı olmayan kuralların önemini her zaman ortaya koymuştur. Çünkü siyasi hayatı yapılandıran "oyunun kuralları"nın çoğu resmi olmayan bir şekilde oluşturulmuş, inşa edilmiş ve resmi yaptırım kanallarının dışında uygulanmıştır. Örneğin Meksika'da Cumhurbaşkanı yıllardır Anayasa, seçim yasası veya parti tüzüklerindeki kurallara göre değil, daha çok mevcut Cumhurbaşkanı'na halefini seçme hakkı veren yazılı olmayan bir kod olan "Dedazo" aracılığıyla seçilmiştir (Langston, 2003). Yine Japonya'da emekli devlet bürokratlarının özel şirketlerde en üst sıralarda ödüllendirildikleri "Amakudari" katı ama yazılı olmayan bir kural olarak uygulanmaya devam etmektedir (Colignon ve Chikako, 2003). Ayrıca Orta Asya'da klan temelli normlar oyunun kuralları haline gelebilmişken; Sovyetler Birliği'nin çöküşü sonrasında oluşturulan Anayasal yapılar giderek önemsiz hale gelmiş ve çoğu ülkede kayırmacılık, yolsuzluk ve patrimonyalizm kalıpları yeni demokratik, piyasa ve devlet kurumlarıyla bir arada var olabilmiştir (Collins, 2002).

Gayri resmi kurumların işlevselliğiyle ilgili olarak, siyasi aktörler, resmi ve gayri resmi teşviklerin karışımına bazen belli bir yanıt geliştirebilmekte ve bazı durumlarda gayri resmi teşvikler resmi olanların önüne geçebilmektedir. Örneğin savaş sonrası İtalya'da yolsuzluk normları devletin yasalarından daha güçlü hale gelmiş ve yasalar cezasızlıkla ihlal edilebilirken, yasadışı piyasanın kurallarına uymayan aktörler belirli bir cezaya çarptırılmıştır (Della Porta ve Vannucci, 1999, s.15). Farklı bir örnek olarak Brezilya'da yasalar, yargı dışı infazları yasaklamış olsa da, kamu güvenliği organındaki gayri resmi kurallar ve prosedürler polis memurlarının bu tür bir cinayete katılmasını mümkün kılabilmiş ve hatta onları teşvik edebilmiştir. Bu nedenle, şüpheli şiddet suçlularını öldüren polis memurları, kovuşturmadan korunacaklarını ve muhtemelen bir terfi veya ikramiye ile ödüllendirileceklerini düşünmüşlerdir (Brinks, 2003, s.1-19). İşte bu gibi durumlarda, resmi kuralların katı bir analizi, güdüleyici davranışları anlamak için yetersiz kalabilmektedir.

Gayri resmi kurallar bazen kurumsal sonuçlara da etki edip şekillendirebilmekte oldukça kritik bir rol oynayabilmiştir. Burada gayri resmi yapılar, 
resmi kurumların performansını önemli derecede ve genellikle beklenmedik şekillerde şekillendirmektedir. Örneğin, yasama ve yürütme ilişkileri her zaman kesin bir şekilde anayasal dizayn ile ilişkili gelişmemiştir. Afrika ve Latin Amerika'daki devlet kurumları üzerinde "Denetimsiz Başkanlık" kontrolüne izin veren neo-patrimonial normlar, genellikle Başkanların anayasal otoritesini fazlasıyla aşan bir düzeyde yürütme hâkimiyeti sağlamıştır. Tam tersi şekilde gayri resmi kurumların Başkanlık yetkisini sınırlayabildiği de görülebilmiştir (O'donnell, 1994, s.55-69). Diğer bir örnek olarak Şili, Anayasal açıdan dünyanın en güçlü Başkanlıklarından birine sahipken; yine de idari danışma ve güç paylaşımını teşvik eden bir dizi gayri resmi kurum nedeniyle Şili Cumhurbaşkanı 1990'larda sistematik olarak anayasal ayrıcalıklarını yetersiz bir şekilde kullanabilmiştir. Sonuç olarak Şili, Başkanlık Sistemlerinin yoğun olduğu Latin Amerika'da bir istisna olarak gösterilmiştir (Siavelis, 2002, s.81).

Gayri resmi kurumlar son olarak seçim kurallarının etkilerini de şekillendirebilmekte ya da resmi kurumsal sonuçları resmi kurallara uymak için teşvikler yaratarak daha az görünür bir şekilde etkileyebilmektedir. Örneğin seçim kurallarıla ilgili olarak, Kosta Rika'nın orantılı temsil sistemi ve Kongre'deki yeniden seçilme yasağ hizmetlerini yerine getirmeleri için resmi bir teşvik sunmamaktadır. Ancak yine de Kosta Rika milletvekilleri, gayri resmi bir şekilde parti yönetimindeki bölgelerde bu tür faaliyetlere rutin olarak katılmaktadırlar (Taylor, 1992). Kurumsal sonuçları zımni bir şekilde etkileyebilmekle ilgili olarak ise, çoğunlukla $\mathrm{ABD}^{\prime}$ deki demokrasinin istikrarında resmi kontrol ve dengelerin devletin organları arasında ciddi çatışmaya dönüşmesini engelleyen nazikçe kaybetme, belirli resmi ayrıcalıkların yetersiz kullanımı ve kritik konularda iki partili fikir birliği gibi gayri resmi kurumların işlevi örnek olarak verilmektedir. Böylece ABD'deki Başkanlık demokrasisinin istikrarının yalnızca Anayasa'da belirtilen kuralların bir ürünü olmadığı, aynı zamanda gayri resmi kurallara da dayanmakta olduğunun altı çizilmektedir (Levitsky, 2001).

Bu çalışmada ise gayri resmi kurumlar mantığı, yeni kurumsalcılığın ikinci dalga düşünürlerine benzer olarak oldukça geniş bir perspektiften ele alınacak ve fikirler olarak gayri resmi kurumların siyasi dönüştürücü etkisi analiz edilmeye çalışılacaktır. Sheri Berman (1998)gibi isimlerin vurguladığı gibi fikirlerin siyaseti dönüştürücü güçlerinin merkeze alınacağı tartışma- 
larda, gayri resmi kurumların negatif işlevi kadar, pozitif işlevlerinin de olabileceği ve siyaset yapımclarının kendi siyasetleri adına fikirler gibi gayri resmi kurumları nasıl pozitif yönde kullanabileceği vurgulanacaktır. Hindistan'daki resmi güç olan iktidarın, gayri resmi kurumlar aracıllğıyla siyasete yön verebildiği gibi, iktidara muhalefet eden siyaset yapımciları da kendi alternatif gayri resmi kurumlarını inşa edip iktidara cevap verebilmektedir. Bu şekilde gayri resmi kurumların hegemonik mücadeleleri altında kitleler de bu kurumsal çatılar altında toplanıp, davranışları şekillendirilip, belli sonuçlar için mobilize edilebilmektedir. Sonuç itibariyle siyaset, resmi kurumlar kadar gayri resmi kurumlar tarafından da belirlenebilmektedir.

\section{Modern Hindistan'da İlk Hegemonik Gayri Resmi Kurum Olarak Sekülerizm}

Hindistan'da bağımsızlık sonrası ülke siyasetine yön veren bir gayri resmi kurum olarak öncelikle sekülerizm üzerinde durulacaktır. Batılı ülkelerde büyük ölçekli sosyal üretim, tüketim ve dağıtım örgütlenmesinin ürünü olarak gelişen sekülerizm, Hindistan'da ise özellikle bağımsızlık sonrası, ülkenin sahip olduğu çeşitliliğin çatışmaya yol açmasını engelleyen ve ülkeyi mobilizasyonlara karşı ayakta tutan en önemli gayri resmi kurum olarak gelişmiştir. Bağımsızlık sonrası kurulmaya çalışılan yeni devlet ve ulus inşası sürecinde, toplumdaki kast, sınıf, etnik ve inanç yönünden var olan çeşitliliklerin çatışma ihtimaline karşı, tüm bu grupların birbirlerine karşı ortak saygısını önceleyen bir gereklilik var olmuştur. Bu çatışmayı önlemeyle ilgili gelişen tarihsel gereklilik, yeni bir siyasal erdemin kurumsallaştırılmasının gerekli görülmesi sonucunu doğurmuştur. Bu açıdan bağımsızlık hareketinin yeni elitleri, bağımsızlık sonrası kurulan yeni devletin sosyal ve politik kurumlarını, sosyal örgütlenmenin geleneksel fikir ve prensiplerine göre dizayn edilmesine sıcak bakmamışlardır. Eskiden Hinduizm başta olmak üzere ülkenin çeşitli bölgelerinde farklılık arz eden çok sayıda inanç bulunmaktayken; bu çeşitliliği bir arada tutacak yeni bir yaklaşıma ihtiyaç duyulmuştur. Burada da tüm süreç, sekülerizme yasal bir fikir olarak devlet politikası ve anayasal inşa sürecinde kurumsal bir meşruiyet verilmesiyle sonuçlanmıştır. Kısaca sekülerizm yeni modern rasyonalitenin ideolojik silahı olarak ortaya konmuştur (Sen, 2004, s.35-40). 
Sekülerizmin Hindistan siyasetinde bir fikir olarak ortaya çımasından yasallaşmasına giden süreç kolay olmamıştır. Doğal olarak toplumun geleneksel kesimleri, özellikle de Hindu geleneksel sosyo-politik yaşam tarzını savunan ve bunun yeni ulus ve devlet sürecine yansitılması gerektiğini vurgulayan kesimleri tarafından engeller çıkartılmıştır. Özellikle Kongre hareketi içerisindeki Tilak liderliğindeki radikaller, bağımsızlık yolunda şiddeti savundukları kadar, muhafazakâr bir pozisyona ve Hindu geleneklerine de sıkı sıkıya bağlılık taşımışlardır (Seth, 2006: 137-150). Müslümanların da Cinnah liderliğinde zamanla ulusal hareketten ayrılması seküler anlayışa yönelen diğer bir darbe olmuştur (Suda, 1969: 155). Diğer yandan ülkede modernitenin ve doğal olarak sekülerizmin hiçbir zaman giremeyeceği kırsal kesimler söz konusu olmuştur. Devletin politikaları buralarda sosyal yaşamı dönüştürme yeteneğine sahip ana sosyal güç olamamıştır. Buralarda toplum geleneksel yaşam tarzına her zaman devam etmiş ve inançlar buralarda tüm alanları domine etmiştir. Özellikle kast siyaseti, yerelden ulusala siyaseti şekillendirmeye devam eden bir sosyal kurum niteliği taşımıştır (Anderson, 2012). Ancak yine de 1960'lara kadar Hindistan'da sekülerizm ülkenin temel tutkalı olmaya devam etmiştir. Geleneksel değerler ülkede var olmaya devam etse de stratejik olarak seküler siyasete angaje olmak zorunda kalınmıştır.

Ülkede sekülerizmin geleneksel tüm engellere rağmen gelişmesinin ardında eş zamanlı olarak milliyetçiliğin gelişmesi yatmaktadır. Aslında tüm kolonizasyon döneminde bile ülke genelinde milliyetçi bir hissiyat eksikliği söz konusu olmuştur. Ancak Ulusal Kongre Hareketi'nin ülkede yavaş yavaş yükselip ulusal bir hareket inşa etmesi geleneksel toplumun ilk defa gelenek dışı bir davranış sergilemesinin önünü açmıştır. Bu noktada sekülerizm ile milliyetçiliği ve hatta Hindu değerleri birleştirerek ulusal bir dalganın ortaya çıkmasına neden olan isim Mahatma Gandi olmuştur. Gandi ulusal anlamda bir mobilizasyon için siyaset ve inançlar arasındaki engeli kaldırmıştır. Gandi'nin “Dinin siyasette hiçbir işe yaramadığını söyleyenler, onun ne anlama geldiğini bilmiyorlar" deyişiyle birlikte, Hindu değerlerine sıkı sıkıya bağlı olan kesimler de harekete dâhil olmaya başlamışlardır (Tandon ve Singh, 2013). Böylece 1920'ye kadar Kongre hareketi Gandi'nin liderliğinde 1 lımlı seküler milliyetçilerin kontrolüne geçmiş ve inançlara sıfır tolerans gösteren radikal seküler milliyetçilerin gücü kırılmıştır. Gandi ulusal bir bilincin doğması için başta Hinduizm olmak üzere tüm inançların 
katkılarının şart olduğuna inanmıştır. Bu yüzden Gandi düşüncesinde derin Hindu atıflar olmasına rağmen, çoğulculuk temelinde bir ulusal hareket paradigması inşa edildiği söylenebilir. Nitekim Hilafet Hareketi'ne bile ilk etapta destek veren Gandi'nin seküler milliyetçiliği, bu sebeple "karma sekülerizm" olarak da anılmıştır (Panigrahi ve Gandhi, 1985: 32).

Gandi'nin şiddet karşıtı, inanç, sınıf ve kast çatışmasının önüne geçen karma seküler yaklaşımı, ulusal hareket nezdinde büyük bir armoni ortaya çıkarmıştır. Ancak Gandi'nin 1lımlı tavrına karşılık, Kongre hareketi içerisinde diğer bir seküler model de kendisini güçlendirmeye başlamıştır. Radikal sekülerist olarak adlandırılabilecek bu grup, Gandiyen model sekülerizme karşı çıkmış ve Hindistan'ın sosyo-ekonomik problemlerinin bu yaklaşımlar aracılığıyla çözülebileceğine inanmamıştır. Bu doğrultuda popüler Hindu retoriğin yerine sınıf çatışması ve sosyal eşitliğin dilinin hâkim k1lınması gerektiği vurgulanmıştır. Bu açıdan gündemlerini sosyalist, demokratik ve seküler bir gündem teşkil etmiştir (Pantham, 1997, s.523-540). Cevahirlal Nehru liderliğinde gelişen bu grup, daha sonra Gandi sonrası hareketi ele geçirince yeniden yaklaşımlarına hayat vermeye çalışmışlar ve bu seküler düşünceyle ülkedeki komünist cephenin de desteklerini arkalarına almışlardır. Ancak Nehru'nun sahip olduğu bu seküler yaklaşım temelli uygulamaya konulan politikalar da belli engellerle yüzleşmek zorunda kalmıştır. Bunların en önde geleni ise yine etnik problemler olmuştur. Her geçen gün tabanların güçlendiren bu Hindu milliyetçileri, Hindu inancı, kültürü ve dilinin başta devlet olmak üzere tüm sosyal yapılara egemen olması gerektiğini iddia etmişlerdir. Sloganları "Hindi, Hindu, Hindustan" olan bu pragmatik ortodoks Hindular, Cinnah'ın Pakistan'da kurmuş olduğu gibi, Hindistan'da bir Hindu ulusu inşa etmek istemişlerdir. Bu açıdan Nehru'nun radikal sekülerizm fikri, Hindu radikaller güçlendikçe belli bir uzlaşma temelinde buluşmak zorunda kalmıştır (Kumar, 2016: 37-40).

Yükselen Hindu radikal eğilimlere karşı ilk etapta uzlaşmacı bit tavır sergileyen tekrar Gandici perspektifi gündeme dâhil etmişlerdir. Nehru burada dini çoğulculuğu kabul etmiş olsa da, daha da önemli Hindu radikallerin gayret gösterdikleri Hindu üstünlügü ve azınlıkların asimilasyonu gibi politikalara da izin vermemiştir. Daha sonra ise Nehru, aynı seküler görüşe sahip olan Bhimrao R. Ambedkar ile birlikte, mevcut uzlaşmacı siyaseti, "dini yansızlık" olarak bilinen sekülerizmin defansif bir stratejisiyle dönüştürmeyi başarmıştır (Balasubramanian, 1980: 101). Dini politikadan 
özellikle siyaset ve devlet politikasında uzak durmaya karşılık gelen bu seküler yaklaşım, Nehru'nun kısa vadedeki zaferini ilan ederken, onun seküler düşünceyi yasallaştırarak kurumsallaştırmasının da ilk adımını teşkil etmiştir. Bu açıdan Nehru, Ambedkar ile birlikte Hindistan'ın sosyalist, demokratik ve seküler bir ülke olduğunu Anayasa'ya dâhil ettirmiştir. Bunun dışında Anayasa'nın 15. Maddesi'nin 1. Furkası'nda devletin din, ırk, kast, cinsiyet ve doğum yeri temelinde hiçbir vatandaşa ayrumcıllk yapmaması gerektiğine yer vermiştir. Yine 16. Madde'nin 1. Furkası'nda devlet istihdamına yönelik olarak tüm vatandaşlar için fursat eşitliğinden bahsedilmiştir. Madde 25'in 1. Fırkası ise dini özgürlüğü garanti eden bir ifadeye sahiplik etmiştir (Indian Constitution, 1949). Tüm bu düzenlemeler, geçici de olsa sekülerizmin ülkede her alanda egemenliğini tesis etmeye yardımcı olmuştur.

Nehru, sekülerizmi yasal kurumsal çerçeveye kavuşturmuş olsa da, bu modelin benimsenmesi için güçlü sosyal desteği mobilize etmekte uzun vadede başarılı olamamış ve radikal sekülerizmin yenilgisini engelleyememiştir. Söz konusu başarısızlık daha çok politik sınırlardan kaynaklanmıştır. Öyle ki Kongre Sistemi çöküşe geçtikçe, sistemin gayri resmi kurumu sekülerizme alternatif her zaman bir adım gerisinde onun düşüşünü bekleyen Hindu milliyetçilerinin Hindutva fikri bir gayri resmi kurum olarak yükselişe geçmiştir. Tabi Hiindutva yükselirken, Kongre Sistemi'nin sekülerizmi de tamamen ortadan kalkmış değildir. Sekülerizm bugün bile ulusal anlamda kural koyan ve davranışları biçimlendiren en önemli iki kurumdan birine karşılık gelmektedir. Dolayısıyla nasıl Kongre Sistemi çökerken sekülerizme alternatif yükselen Hindutva gibi kurumlar kitlesel mobilizasyonun moral ekonomisini teşkil etmişken; benzer şekilde bugün de BJP karşıtı oluşan cephenin moral ekonomik çerçevesini en fazla dolduran seküler değerlerdir denilebilir. 2019 seçimleri de bu manada gayri resmi kurumların bir çatışma alanı olarak takip edilebilmiştir.

\section{Yeni Hegemonik Gayri Resmi Kurum: Hindutva'nın Yükselişi}

Hindistan'da gayri resmi hegemonyaya sahip olan sekülerizm fikrinin zayıflamasının etkisiyle, onun yerine ve ona karşı yükselen en önemli gayri resmi kurum şüphesiz Hindu milliyetçiliğinin baskın formu olan Hindutva (Hinduluk) olmuştur. Hindutva kavramı, ilk olarak 1923'te Hindu milliyet- 
çiliğinin ilk öne çıkan yorumcusu Vinayak Damodar Savarkar tarafından kullanılmıştır(Savarkar, 2003). 1924'te ise Hindu milliyetçiliğinin temel ilkelerini açıklamak için 'Hindutva' adlı bir kitap yazmıştır. 1925' te ise Hinduları Müslümanların "saldırganlıklarından" korumak için RSS (Rashtriya Swayam Sevak Sangh) kurulmuştur (Curran, 1950, 93-98). Keshav Baliram Hedgewar tarafından kurulan RSS, devam eden dönemde Savarkar ile birlikte Hindutvayı, Mahatma Gandi ve Kongre tarafından öne sürülen bileşik Hindistan milliyetçiliğine karşı yaymaya çalışmıştır. Hedgewar sonrası RSS'nin başına geçen M.S. Golwalkar da Hindutva'ya yeni yorumlar katarak zenginleştirmiştir. Bu üç isim başta olmak üzere birçok Hindutva taraftarı olan düşünür, daha sonraki yıllarda fikre büyük katkı yapmışlar ve özellikle 2014 BJP iktidarıla birlikte Hindutva ülke siyasetinin merkezine yerleşmeye başlamıştır. Bu doğrultuda Hindu bireyin nasıl olması gerektiğinden Dharma adı verilen hayatın kurallarına, Hindu Rashtra (Hindu Ulusu) inşasından sosyal düzen ilişkilerine kadar tüm alanları doldurmaya çalışarak geniş bir çerçeve sunan Hindutva, bir taraftan mobilize olan kitleleri kendi çatısı altında toplayarak mobilizasyonu kontrol altına almışken, diğer taraftan da kendi amaçları doğrultusunda bir mobilize edici işlev görerek belli bir sonuca etki etme kapasitesine sahip olmuştur.

Belli düzeyde mobilize olmuş kitlelere adapte olunabilir bir yol sunarak sosyal etkileşim ve koordinasyonu arttıran bu düşüncenin mimarı Savarkar'dır. Hindistan'da ulus inşasının en önde gelen isimlerinden biri olarak değerlendirilen Savarkar'ın burada bir gayri resmi kurum olarak Hindutva'nın gelişimindeki ulus, devlet ve azınlıklarla ilgili görüşlerinden yararlanılmıştır. Her şeyden önce Joseph Mazzini'den ödünç aldığı Hindistan milliyetçiliği kavramını Savarkar'ın, daha sonraları Hindu milliyetçiliği lehine terk ettiği görülmektedir (Jaffrelot, 1999: 26). Başka bir deyişle Savarkar ilk etapta İtalya'nın birleşmesine öncülük eden Mazzini'nin fikirleriyle Hindistan'ın birleşmesini savunmuş, ancak daha sonraları birleşmesi gerekenin sadece Hindular olduğuna dair fikrini değiştirmiştir. Bu bağlamda Hindi milliyetçiliği için kendi kavramı olan Hindutva'yı geliştiren Savarkar, teritoryal milliyetçilik kavramını da reddetmiş ve belli bir toprağın ulusunu ortaya çıkarmayacağını, ulusun kendilerini kültürel yakınlıklar ve gelenekler ile birbirine bağlanmış, siyasi bir topluluk oluşturan insanlar tarafından ortaya çıarılabileceğini ifade etmiştir (Gafoor ve Noorani, 2002: 61). Bu açıdan Hindutva'yı bir kültürel milliyetçilik olarak ele alan Savarkar için 
kimlik oluşumu milliyetçiliğin temeli olarak görülmüştür (Joglekar, 2006: 4). Hindistan'da bu kimlik Hindu inancından kaynaklanmış ve uzun bir inşa sürecinden geçmiştir. Dışsal farklılıklara rağmen, Hindular kültürel, dini, sosyal, dilsel ve tarihsel yakınlıklarla içsel olarak birbirine bağlanmıştır. $\mathrm{Bu}$ yakınlıklar, asimilasyon ve yüzyıllar boyunca sayısız birleşme sürecinde gelişmiştir. Bu süreç de Hinduları homojen ve organik bir ulus haline getirmiş ve hepsinden öte ortak bir ulusal hayata irade kazandırmıştır. Savarkar açısından toplumdaki diğer bölümler farklı kültürel geleneklere sahip olduğu için homojenlik önemli görülmüştür (Devare, 2013:210).

Ulus oluşumunda en fazla katkı sağlayanın kültürel, ırksal ve dini birlik olduğunu savunan Savarkar, birinci derecede öneme sahip olmamasına rağmen, ancak ulusun diğer uluslarla mücadelesinde güçlü olabilmesi adına belli bir toprağı kontrol etmesine ve üzerinde kurulmuş bir devlet sistemine büyük önem vermiştir. Tabi modern zamanlarda ulusun uygulanabilir tek siyasi varlık olarak tanındığı ve tüm dünya toplumlarının ulus temelinde örgütlendiği için söz konusu devlet de Hindu ulusu temelinde örgütlenmeli ve ulusal politikalarını Hindu ulusu bağlamında üretmeliydi. Bir Hindu Devleti bu açıdan Savarkar düşüncesinde önemli bir kriterken, buradaki en fazla önem arz eden konu azınlıkların durumunun ne olacağ konusudur. Bu açıdan söz konusu ulus ise Savarkar, Hinduların dışındaki kimseyi ulusa dahil etmemiş ve başta Müslümanlar ve Hıristiyanlar olmak üzere hepsinin dışlanması gerektiğini iddia etmiştir. Bunun sebebi olarak da azınlıkların Hindistan'ı kutsal toprakları olarak kabul etmemelerini öne sürmüştür. Diğer yandan söz konusu devlet ise Savarkar için durum farklıydı ve azınlıklar, Hindu ulusunun bir parçası olmayacaklarken, devletin bir parçası olmaktan başka çareleri yoktu. Çünkü ulus, kültürel bir kategoriyken; devlet, politik bir kategoriydi. Bu açıdan Savarkar'da azınlık hakları konusunda mecburi bir kabullenme durumu mevcutken; yine de azınlıklar tarafından geliştirilen özel çıkarların reddi konusunda bir geri adım söz konusu değildir (Jaffrelot, 1999).

Hindutva'yı devasa Hindu grubuna bağlı bireylerin davranışları için bir yol gösterici çerçeve olan tasarlayan Savarkar'dan sonra, kavramı geliştiren ve organizasyonel temelle de güçlendirerek kitlesel anlamda büyümesine yardımcı olan yapı ise Ulusal Gönüllüler Birliği (RSS) olmuştur. Hindular'ın çıkarlarını korumak için Keshav Baliram Hedgewar tarafından kurulan RSS, Hedgewar' in Kongre'deki radikallerin lideri Lokmanya Tilak ile iyi ilişkilere 
sahip olması nedeniyle Kalküta'da bazı silahlı radikallerle temas kurarak daha militer bir örgüt olarak ortaya çıkmıştır (Chitkara, 1997: 87). Hedgewar, Hindu toplumunun örgütsüz ve düzensiz doğası nedeniyle, Hinduların toplumsal isyanlarda zarar gördügünü düşünmüştür. Bu nedenle, menfaatlerini korumak için güçlü bir Hindu örgütü kurmaya karar vermiştir. Bu açıdan 1925'te kurulan RSS, siyasete katılmamış daha kültürel bir organizasyon görüntüsünde olmuştur. Hedgewar, RSS'yi üç amaç etrafında kurmuştur: 1- Çıkarlarını korumak ve tüm faaliyetlerinde birliği ve tutarlılığı sağlamak için Hinduların seferber edilmesi, 2- İngiliz militan ve komünal Müslüman siyasetine ve Müslümanların yatıştırılması politikasını izleyen Kongreye muhalefet edilmesi, 3- Sabırla örgütsel çalışma yaparak ve vatanseverlik ruhunu telkin ederek RSS'in yaşamın her kesimindeki etkisini artırmak. Bu açıdan Hedgewar'a göre, RSS'nin temel amacı politik gücü yakalamak değil, Hinduların ülkenin kamusal yaşamındaki etkisini arttırmaktır. Hedgewar zamanında, RSS, beyaz yakalı orta sınıflar arasında popülaritesini arttırmıştır. RSS, 1930 sivil itaatsizlik hareketinde yer almamış ve Hindu Mahasabha'nın siyasi faaliyetlerine doğrudan dâhil olmamıştır. 1940'ta ise Hedgewar, RSS'in Başkanı olarak bir üniversite Profesörü olan Madhav Golwalkar'1 atamıştır. 1973'e kadar RSS'nin başında kalan Golwalkar, Hindutva fikrine katkı yapan diğer önemli bir isim olmuştur (Parvathy, 2003: 86).

Golwalkar'in Hindutva'ya yaklaşımı, milliyetçilik teorisinin Hint maneviyatına dayandığı ölçüde Savarkar'dan farklı olmuştur. Savarkar modernist ve Batılılaşmaya karşı değilken; Golwalkar, Hindu kültürünün destekçisi ve Batı yaşam tarzına karşı bir pozisyon almıştır (Purohit, 1965: 72). Hint maneviyatçllı̆ın Batı materyalizminden üstün olduğuna inanan Golwalkar, Hindistan'ın kutsal bir toprağa sahip olduğuna ve bu yüzden Hindistan'ın dünyaya liderlik etmesi için ilahi irade sahibi olduğuna inanmıştır. Bu açıdan Golwalkar da bir kültürel milliyetçilik savunuculuğu yapmış ve milliyetçiliği anavatana olan sevgisiyle eş değer görmüştür (Hoveyda, 2010: 45). O da Hindular'ın Hindistan'ı anavatan olarak gördüklerini, çünkü binlerce yıldan beri bu kutsal toprakla özdeşleştirildiklerini iddia etmiştir. Bu açıdan bu eski toprakların çocuklarının yakın bir geçmişte ulus halini aldığı yanlış bir tespitken, bunun ona göre Hindistan binlerce yıldan beri bir ulus olarak var olmuştur (Parvathy, 2003: 52). 
Kültürel milliyetçilik anlayışını benimseyen Golwalkar, bu sebeple doğal olarak teritoryal bir milliyetçiliğe karşı olmuştur. Teritoryal milliyetçilik, ülkenin bölünmesine neden olan bölücü ve ulusal karşıtı bir gündemi barındırdığı için, Hindistan'ın parçalara ayrılması da aslında teritoryal milliyetçiliğin bir sonucu olarak görülmüştür. Bu sebeple Golwalkar'ın kültürel milliyetçiliği beş ilkeye dayanmıştır: ortak din, ortak ırk, ortak dil, ortak kültür ve ortak ülke (Jaffrelot: 2010: 133). Bu beş ilke, halkın zihninde ulusal bilincin oluşmasına yardımcı olmuştur. Diğer yandan Golwalkar, Hindu ulusunun karakterini tartışırken belli unsurların altını çizmiştir. Bitişik bölgelerin varlığı üzerine oturmuş bir vatan iması birinci unsuru oluşturmuşken; ikinci unsur, o ülkeyi işgal eden halkın özellikleridir. Halkın bu toprakları kutsal topraklar ve vatan olarak görmesi gerektiği için, ortak kültür, ortak gelenekler, ortak tarihsel geçmiş ve ortak ideallerle birleştirilmek gerekmektedir. Bu ortaklık da onları bir araya getirip kendi yaşam tarzlarını geliştirmelerine yardımcı olacaktır. Üçüncü unsur, o bölgede yaşayan insanların ortak ekonomik çıkarlarıdır. Tüm bu unsurlar ülkenin ulusal karakterinin kazanılmasına katkıda bulunmaktadır. Böylece, Golwalkar'ın Hindu milliyetçiliğinde kültürel faktörler çok önemli bir rol oynamıştır. Bu nedenle, doğru eğitim ve öğretimi sağlayarak insanların zihinlerinde doğru tutum türünün geliştirilmesine vurgu yapmıştır. Bu açıdan Hindu inancının insanlara doğru türde değerler ve uygulamalar sağlama noktasında faydalı olduğu kanaatinde olmuştur. Bu durum, Hindu ulusunun birlik ve birliğin ruhu ile titreşen ulusal organizmaya evrimleştiği noktaya karşllık gelmiştir (Jaffrelot: 2010: 141).

Golwalkar, Hindutva fikrine önemli bir diğer katkısı, pozitif ve negatif Hindutva ayrımlarıdır. Ona göre, negatif Hindutva, Müslüman komünalizmine ve Kongre sekülerizmine bir reaksiyon olarak gelişmiş ve nefret temellidir. Müslüman ve seküler güçleri, "ötekiler" pozisyonuna atan negatif Hindutva, bu kesimlere karşı siyasal gücü elde tutmanın aracı olmaktadır. Pozitif Hindutva ise, bir reaksiyon ya da nefret temelli olmaktan ziyade, toplumda bir sosyal güç olarak Hinduların örgütlenmesini savunmaktadır. Siyasal gücün yardımı ile tüm sorunların çözülmesinin mümkün olmadığı tarihsel deneyimlerle tecrübe edildiği için, pozitif Hindutva'nın temel amacı siyasal gücü ele geçirmek değildir. Hindu topluluğunun esnekliğinin sırrı hayata karşı tutumlarında bulunabilmektedir (Parvathy, 1994: 117). Onlar sosyal ve siyasal organizasyonların, siyasal güç temelinde değil, hayatın 
kurallarına karşılık gelen "Dharma" temelinde kurmuşlardır. Eski zamanlarda Dharma'ya uymayan Kral'a bile saygi duyulmazken, Hindu toplumu bu kuralları modern toplum dönemine de taşıyabilmiştir. Bunun için siyasal gücün dişında kalınmalıyken, ancak yine de dışarıdan kontrol edilmesi şarttır. Bu nedenle RSS, siyasal iktidara hiç soyunmamış ve daha çok örgütlü, güçlü ve birleşik toplum ve bireyleri yetiştirmek için bir organizasyon olarak yoluna devam etmiştir. Ayrıca siyasal gücün önemli olmadığı belirtilse de, Hindu ulusunun geleceği için egemenlik ve ulusal güç oldukça büyük önem arz etmiştir (Sharma, 2007: 27).

Görüldüğü üzere Hindutva fikri, tek tek bireylerden, topluma ve ulusa kadar nasıl bir davranış kalıbına sahip olunması gerektiğini ortaya koyarak her bir bileşenin uyması gereken kuralları sıralamıştır. Hindutva bu şekilde sekülerizmin de zayıfladığı dönemlerde, başta Hindu toplumu olmak üzere Hindistan' 1 birçok bölgesinde etkinliğini arttırabilmiştir. Janata Parti ve BJP gibi partilerin politikalarında merkezi teşkil etmesiyle de fikir, ülke siyasetinde oyunun kuralların değiştiren gayri resmi bir kurum niteliğine iyice bürünmüştür. Öyle ki Hindutva yaklaşımı üzerinden partiler kendi kadrolarını oluşturabilmiş, seçmenler oy davranışlarını şekillendirebilmiş ve iktidar gündemini oluşturabilmiştir. İç siyasetin yanında Hindutva, dış siyasette de eski kuralları değiştiren bir rol oynamıştır. Öyle ki Kongre Partisi'nin bağlantısızlar geleneğinden gelen agresif olmayan bir dış politika tercihi, Hindutva siyasetini merkezine alan BJP döneminde değişmiştir. BJP’nin bu tercih değişikliğinde Hindutva'nın etkisi büyükken, Akhand Bharat (Bölünmemiş Hindistan) gibi yeni jeopolitik tahayyüller içeren bir aktifliğe geçilmiştir (Trivedi, 2017: 105). Tabi dönüştürme kapasitesi böylesine güçlü olan bir gayri resmi kurum olarak Hindutva, geniş kitlelerin mobilize olarak çatısı altında toplandığı problem çözen bir yapıya sahip olmanın yanında, bir o kadar iç ve dış çevresinde rahatsızlık oluşturarak problem doğuran bir gayri resmi kurum olarak da algılanabilmiştir. Bu durum da faklı gayri resmi kurumların ortaya çıkmasına yol açan bir atmosferi ortaya çıkarmıştır.

\section{Hindutva Karşıtı Yükselen Alternatif Gayri Resmi Kurumlar}

Hindistan'da siyaseti dönüştüren ve Kongre sekülerizminin yerine geçen Hindutva gayri resmi kurumunun grup dışı bileşenleri reddedici ve dışlayıc1 karakteri, doğal olarak büyük çeşitlilik arz eden Hindistan toplumunda 
kendisini Hindutva sınırları içerisinde tanımlamayan kesimlerin mobilizasyonuna neden olmuştur. Hindutva siyaseti üzerinden seçim siyasetinde bir türlü var olamadığı bölgelerdeki etkinliğini arttırmak isteyen BJP elitlerinin takip ettikleri Hindutva gündemi de bu noktada oldukça etkili olmuştur. Bu doğrultuda BJP'nin karşısında olan muhalefet elitleri, kimi zaman kültürel değerlerle, kimi zaman dilsel milliyetçilikle, kimi zaman da geleneksel gayri resmi kurumlara yeniden başvurarak ulusal ya da bölgesel düzlemde inşa ettikleri alternatif gayri resmi kurumlarla hem kendi tabanlarını konsolide etmeye çalışmışlar hem de tüm seçmenleri kendileri lehine mobilize etmeyi denemişlerdir. Hindistan'da son dönemlerde Hindutva karşıtı yükselen ulusal veya bölgesel çok sayıda gayri resmi kurum örneğine rastlanabilecekken; burada ulusal düzeyde Ambedkarizm, bölgesel düzeyde de Hilsa, Keralite, Dravidanadu, Tamillik ele alınacaktır.

Hindistan'da BJP iktidarının takip ettiği Hindutva gündemi zımni bir şekilde kast ve sınıf siyasetiyle oldukça ilişkili olduğundan, kimliksel açıdan nasıl Müslümanlar büyük bir şiddete maruz kalıyorlarsa benzer bir şiddete maruz kalan kesim de Dalitler'dir. Kast sisteminin dişında kalan ve "dokunulmazlar" olarak anılan Dalitler, ülkenin kuruluş dönemlerinden bu yana sahip olduğu sosyo-politik düzenin en önde gelen kaybedenlerinden olagelmiştir. Bu açıdan Dalitlerin haklarını savunan Dalit hareketi de oldukça eski bir tarihe dayanmaktayken; bu hareketin en önde gelen isimlerinden birisi de Ambedkar olarak kabul edilmektedir. "Dalitlerin Babası" olarak bilinen Ambedkar'ın Dalit haklarını savunmak için geliştirmiş olduğu kast karşıtı, özgürlükçü ve sosyal adaleti savunan öğreti ve düşünceleri de Ambedkarizm olarak literatürde yerini almıştır (Omvedt, 1994, 223-259). Ambedkarizm çerçevesinde katı kast sistemi ve onun Dalitlere yönelik zalim uygulamalarına karşı mücadelede önemli teorik katkılarda bulunmuş olan Ambedkar, diğer yandan Dalit hareketinin örgütlenmesi adına büyük bir çaba sarf etmiş ve bir sosyal reformcu olmanın yanında bir siyasal lider olarak da harekete katkı sağlamıştır. Fikirsel açıdan kast sistemi ve sistemin Brahmanc üstünlügünü, Dalitlerin özgürlüğü ve eşitlik perspektifinde eleştiren Ambedkar, hareketin siyasallaşması adına da Bağımsız İşçi Partisi'nden Hindistan Cumhuriyetçi Partisi'ne ve Tarifeli Kast Federasyonu'na kadar birçok örgütsel girişime de öncülük etmiştir (Gokhale, 1993,s.142). Böylece Ambedkar'ın düşünce ve eylemleriyle temeli atılan Ambedkarizm, bugün de hala güçlü bir gayri resmi kurum olarak Dalitler gibi kendisini 
sistem tarafından ezilmiş hisseden kitlelerin sığınabildiği bir platform görevi görebilmektedir (Joseph, 1986,s.60-61). Ambedkarizm'in gelişmeye devam eden güncel meselelerdeki düşünce ve öğretileriyle kitleler, belli konularda belli tavirlar takınarak sonuca etki edebilmektedir. Yani kural koyabildiği gibi, uygulatma kapasitesine de sahiptir.

Hindutva'ya alternatif bölgesel düzlemde yükselen ile ele alacağımız gayri resmi kurum Hilsa'dır. Hilsa, Batı Bengal'de BJP'nin kitleleri Hindutva üzerinden mobilize etme girişimlerine karşı, Batı Bengal Başbakanı Mamata Banerjee'nin kendi tabanını koruma adına bir reaksiyon olarak icat ettiği gayri resmi kurumdur. Hilsa'nın ne olduğuna baktı̆̆ımız zaman, Bangladeş kıyılarından Batı Bengal kıyılarına akıntı eşliğinde gelen ve özellikle Batı Bengal'de oldukça popüler bir simgeye sahip olan bir balık türü olduğu görülmektedir. Hilsa'nın gayri resmi bir kurum haline dönüşme süreci ise Bangladeş'ten Batı Bengal sınırları içerisine giren gayri resmi göçmenlerin yeniden ülke gündemine girmesiyle başlamıştır. BJP'nin Hindutva oylarını göçmen karşıtllğı üzerinden arttırma amaçlı politikası, Mamata'nın güçlü tepkisiyle karşılaşmıştı. Mamata'nın Bengalli sınır ötesinden gelen her şeye ajan veya mülteci gözüyle bakan BJP Başkanı Amit Şah'a yönelik "Bay Amit Şah, Hilsa yemiyor, ancak biz yiyoruz. Hilsa burada bulunduğu gibi Bangladeş’te de bulunmakta. Peki, Hilsa da illegal bir göçmen mi?" şeklindeki ifadesi, Hilsa üzerinden yeni bir çerçeve oluşturma imkânı ortaya çıkarmıştır(Kundu, 2018). Öyle ki Mamata, BJP’nin yeni stratejisiyle bölgede yükselmeye başlayan Hindutva siyasetine karşılık, Hilsa sembolü aracılığıyla Bengal kimliğine atıf yapmış ve kendini Bengalli hisseden herkesi Hilsa çatısı altında toplanmaya davet etmiştir. Böylece ulusal anlamda yeni kurallar koyarak geniş kitlesel davranışlar üreten ve siyaseti yeniden dizayn eden Hindutva siyasetine bir reaksiyon olarak Hilsa siyaseti mobilize edilmiş ve bir gayri resmi kurum olarak bölgesel bir davranış kalıbı üretilmeye çalışılmıştır (Pisharoty, 2018).

Hindutva'nın baskısı altında yükselen diğer bir bölgesel gayri resmi kurum Tamil Nadu bölgesinde gelişme göstermiştir. Burada da itiraz, dil üzerinden yükseltilmiş ve Tamil dil milliyetçiliği eyalet partilerinin ulusal formasyonlara karşı mobilize olabilmesine yardımcı olmuştur. Tamilliğin bir gayri resmi kurum kategorisine dâhil eden bugünkü durum, Dravidian İlerleme Federasyonu (Dravida Munnetra Kazhagam - DMK) isimli Dravidian ırkından adını alan partinin, Tamil Nadu'da Hintçe üzerinden baskı 
yaptığını iddia ettiği BJP’ye karşı bir çıkış yapmasıyla ortaya çıkmıştır (Iyer, 2017). Akabinde DMK ve BJP arasında karşlıklı atışmalarla yükselen gerilim, tarihsel açıdan kırılganlık taşıyan fay hatlarını harekete geçirince, Batı Bengal'daki Hilsa'ya benzer şekilde, bir saldırıya karşı korumacı bir tepki olarak ve de problem çözen gayri resmi bir kurum olarak Tamil kimlik ve değerleri aracılığıyla kültürel değerler öne çıkarılmıştır. Aslında DMK, Tamil kimliğinden daha büyük bir kimliğe, Dravidian ırkına atıfta bulunan bir partidir, ancak ulusal ve bölgesel gelişmeler partiyi daha çok Tamillik üzerine siyaset yapmaya kanalize etmiştir (Stalin Hits Out, 2017). Burada da Hindistan'ın her zaman alev almaya hazır dil sorunu üzerinden ilerlenmiştir. Sonuç olarak Tamil Naduluların dil siyaseti aracılığıyla, kendi geleneksel düzenlerine müdahalede bulunan merkeze karşı, Tamil gelenek, norm, değer ve duyguları üzerinden net bir sınır çektikleri görülmektedir. Böylece inşa edilen gayri resmi kurum olarak Tamillik, Hindutva siyasetinin kullanışlı bileşenlerini sınırlamakta ve Tamil Nadu'ya girişine izin vermemektedir.

Hindistan' da gayri resmi siyasetin gelişme ihtimalinin belki de en düşük olduğu yer olan Kerala'da, iktidarın Hindutva siyasetinin etkisiyle gelişen Keralalılık refleksi gayri resmi kurumsal siyaset açısından oldukça özgün bir örnektir. Öyle ki 1970'li ylllardan beri Kerala siyasetini domine eden sosyal demokrat parti olan HKP(M) (Hindistan Komünist Partisi-Marksist), en başindan bu yana hiçbir vakit kimlik siyaseti takip etmemiş, aksine her zaman sinıf siyasetini tercih etmiştir. Hindutva siyasetinin Kerala'ya müdahalesinin başarılı olma durumunda sınıf siyasetinden kimlik siyasetine geçecek eyalette yeni bir sosyolojik yapılanma gerçekleşeceği için, bu durum HKP(M) yönetimini doğal olarak telaşlandırmış ve hem siyasal elitler hem de Kerala halkı kitlesel bir tepki ortaya koymuştur. Bu açıdan Kerala siyaseti eyalet kimliği konusunda belli bir deneyimi ilk olarak 2017 yılında yaşamıştır. Başbakan Modi, BJP'nin parti mitinginde yapmış olduğu konuşmada, gelişme açısından Kerala'yı Somali'ye benzetince bugüne kadar gelişme ve insani değerler konusunda dünyada ün yapmış Kerala'daki sakinler, başta orta sinıflar olmak üzere eyaletlerini Kerala değerleri üzerinden savunmaya geçmişlerdir(Indian PMModi, 2016). Modi'ye cevabı eğitim seviyesi oranları üzerinden vermeye çalışan Keralalılar, tepki olarak "PoMoneModi" adında bir hashtag açmışlardır. "Po Mone" ifadesiyle kelimenin tam anlamıyla "geri 
dön evlat" anlamına gelen popüler bir film repliği kullanılmıştır (\#PoMoneModi: Go, 2016).

HKP(M) kendi siyasal ideolojisi gereği, "PoMoneModi" meselesini gündeminde fazla tutmamışken, BJP'nin geri adım atmayıp halka açık satış yerlerinde kesim için sığır satışını yasaklayan bildirisi, Keralalıların yanında Kerala yönetiminin de meseleye dahil olmasina sebep olmuştur. Çünkü bildiriyle yasaklanan sığır satışı en fazla Kerala'yı etkiliyordu ve söz konusu hamle Keralalılara karşı yapılmıştı. Bunun üzerine Kerala Başbakanı Pinarayi Vijayan, hedef alınan şeyin aslında Kerala kültür ve değerleri olduğunu iddia ederek yasağa şiddetli bir şekilde karşı çıkmıştır. Kerala Başbakanı tarafından konu, Modi yönetiminin tüm ülkede Hindutva kültürünü yayma çabası olarak değerlendirilmiştir (Don't Need Lesson, 2017). Netice itibariyle hem Kerala yönetimi hem de Kerala halkı kendi değerlerine yöneltilen bir saldırı karşısında, Keralalılık bağlamında topyekûn savunmaya geçmişlerdir. Keralalılık bir bölgesel değer olarak, ulusal çapta Hindutva değerlerine set çekerek çevreden gelen etkilerle kurumsal değişime uğrama tehdidini boşa çıkarmıştır. Burada da Keralalılık bir gayri resmi kurum olarak hem defansif hem de problem çözen bir karakterde işlev göstermekte ve HKP(M) gibi ideolojik yönü ağır basan bir partinin pragmatist bir yaklaşımla gayri resmi kurumsal siyasetin önünü açması parti için de yeni bir duruma karşılık gelmektedir.

Son olarak Dravidanadu (Dravidileri Toprakları) eskiden var olmuş, lakin tarih sahnesinden geçici olarak ayrılmış ve gayri resmi siyasetin yükselişinin yaşandığı bu dönemde belli kural, norm, değer ve duygular üzerinden yeniden tarih sahnesine dönen gayri resmi kurumlar için en güzel örneklerden birini teşkil etmektedir. Öyle ki Dravidanadu, Kuzey Hindistan Aryanlarının aksine, Güney Hindistan ile coğrafi olarak tanımlanmış, sakinlerinin Dravidi ırkına ait olan ayrı bir millet tahayyülüdür ve kökenleri 1920'li yıllara dayanmaktadır. Kavramı öne çıkaran ilk girişimlerden biri, Periyar olarak bilinen sosyal reformcu E.V. Ramasamy'nin önderlik ettiği Tamil Nadu'daki Dravidyan hareketidir (Pandian, 1987, s.57-71). Tamil Nadu'da Periyar liderliğindeki Adalet Partisi ve C. N. Annadurai liderliğindeki Dravidi İlerleme Federasyonu (DMK), Dravidilerin birliğini tahayyül edilen bir devlet üzerinden sağlamaya girişmişlerdir. Bu açıdan ilk etapta fikir, daha çok Tamil dilini konuşanların yoğunlukta olduğu bölgeyle sinırlıyken, daha sonraları Dravidi dilini konuşan Andhra Pradesh, Telangana, Kerala and 
Karnataka gibi yerleri de kapsamıştır. Hatta Sri Lanka, Orissa ve Maharashtra'ya kadar genişlemiştir. Diğer yanda 1940 ve 1960 yılları arasında Dravidanadu hareketi en güçlü dönemini yaşamış olsa da, Tamil hegemonyası korkusuyla Tamil Nadu dışında var olan destekleri kaybetmiştir (Batnett, 2015, s.92-93)

Dravidanadu fikrinin yeniden bir gayri resmi kurum olarak ortaya çıkışı ise, Hindutva siyasetinin tüm ülkedeki seküler siyasete zarar verdiğini düşünen HKP(M)'li Comrade Nambiar'ın Kerala'nın seküler topraklara sahip olduğuna ve gerekli görülürse "Dravidanadu" için ayaklanacaklarına dair sosyal medya paylaşmış olduğu görüşüyle ortaya çıkmıştır. Nambiar'ın 28 Mayıs 2017 tarihinde atmış olduğu tweeti sonrasında, Dravidanadu trend konusu haline gelmiş ve başta Keralalılar olmak üzere Güney Hindistan'da yaşayan Dravidi kesimlerden büyük destek görerek büyük bir ivmelenme ortaya çıkarmıştır (DravidaNadu Demand Revives, 2017). Burada ilginç olan bir nokta, Nambiar'ın Keralalı bir Marksist olarak tweet atması ve böyle bir profilden beklenmeyecek şekilde Dravidanadu fikrini desteklemesidir. $\mathrm{Bu}$ durum, Hindutva siyasetinin gayri resmi siyaset kapasitesine sahip olmayan kitleler üzerinde nasıl bir dönüştürücü etki yaptığını ortaya koyan bir göstergedir. Söz konusu Dravidanadu trend konusu, dar anlamda aslında Modi liderliğindeki Birlik Hükümeti'nin yeni sığır ticareti kurallarına bir cevaptır (How Slaughter Ban, 2017). Ancak diğer yandan geniş bir jeopolitiğe sahip bir aidiyet hissini uyandırarak ülkede bölgesel siyasetin ötesinde oyunun kurallarını yeniden yazan bir mekaniği devreye sokmuştur. Hindutva karşısında bu kadar geniş bir alanda etkin olabilen tek gayri resmi kurum sekülerizmken, şimdi benzer bir işlevi Dravidanadu fikri de görmeye başlamıştır.

\section{Sonuç}

Çalışmada görüldüğüü üzere Hindistan siyasetinde kural koyma, davranışlanı şekillendirme ve sonuca etki etme noktasın gayri resmi kurumlar çok etkin ve işlevseldir. Ancak siyaseti doğası gereği her bir gayri resmi kurum farklı sosyo-politik çıkarlara hitap edebilmektedir. Bu durum da kurumsal bir hegemonik mücadeleyi ortaya çıarmakta ve kitlelerin çatısı altına girmek isteyecekleri gayri resmi yapılar arası bir rekabete neden olmaktadır. Hindistan'da modern dönemlerin belki de en önde gelen kural koyucu 
ideolojisi milliyetçilik olmuştur denebilir. Sömürge sonrası dönemde postkolonyal milliyetçilik, içeride kimi zaman liberal kimi zaman da seküler ağırlıklı bir milliyetçilik türü ortaya çıkarmışken; her zaman mücadele ettiği tür kültürel milliyetçilik türü olmuştur. Bugün de Hindu milliyetçiliği merkezli ilerleyen kültürel milliyetçilik, ülkede nasıl bir milliyetçiliğin egemen olması gerektiği konusunda sekülerizmle büyük bir mücadele vermektedir. $\mathrm{Bu}$ açıdan ülkede Hindu milliyetçiliği ile sekülerizmin iki ana akım gayri resmi kurumu temsil ettiği söylenebilir. Kitleler bağımsızlık sonrası dönemde seküler kurallar çerçevesinde davranışlarını şekillendirmeye daha fazla meyletmişlerken; küreselleşme, postmodernizm gibi trendler sebebiyle ülkede yükselen kimlik siyaseti Hindu çoğunluğu mobilize etmiş ve Hindutva çatısı altında birleştirmiştir. Şuan ülkede davranışları şekillendirebilen en güçlü gayri resmi kurum Hindutva'dır; ancak sekülerizm tamamen ortadan kalkmadığ gibi, Hindutva karşıtı alternatif gayri resmi kurumlar da kitleler nezdinde her geçen gün etkisini arttırmaktadır. Bunlar da çoğunlukla daha önce seküler siyaset kurallarının hâkim olmasına rağmen, Hindutva ile yükselen kimlik siyasetine bir yanıt mahiyetinde ortaya çımaktadır. Ancak gayri resmi kurumların en önemli özelliklerinden birisi, resmi kurumlardan farklı olarak yazılı olmadıkları için her şart ve duruma göre değişip kendilerini güncelleyebilmeleridir.

Hindistan'daki gayri resmi kurumlar şiddetli bir hegemonik mücadele içindeyken; hegemonik pozisyonunu kaybeden kurumların belli bir patikabağımlılığa sahip olduğu ve kurumsal değişim tartışmalanyla ilgili olarak yeniden eski gücüne kavuşabilecekleri şuan Hindistan siyasetinde oldukça tartışılan bir konudur. Burada gayri resmi kurumların fikirsel açlımları not edilmesi gereken noktaya karşılık gelmektedir. Öyle ki nasıl sekülerizm hegemonik bir poziyona sahipken, Hindu milliyetçileri Kongre sekülerizmini "yalancı sekülerizm" olarak değerlendirerek kendileri "pozitif sekülerizm" vurgusu yapmışlarsa, bugün Kongre'nin de benzer bir davranış sergileyebileceği tartışılmaktadır. Nitekim Kongre Partisi'nin de Hindutva'nın etki kapasitesine karşı Hindu ritüellerine dışlayıcı olmadan atıfta bulunan "Soft Hindutva" yaklaşımını benimsediği iddia edilmektedir. Dolayısıyla kurumsal değişim çerçevesinde mevcut gayri resmi kurumların kendi bünyelerindeki kurallarda değişime giderek, yükselen ilgi ve çıkar alanlarına yönelik esneklik göstermeleri stratejik dizayn çerçevesinde tartışılmaya açı bir konudur. Nitekim Hindistan'daki diğer gayri resmi kurumların elitleri 
de benzer dizayn hamleleri yapabilmektedir. Örneğin Dalitlerin haklarını savunan Ambedkarizm, kendi fikri yapısını geliştirerek Dalitler dışında ezilen diğer sosyal kesimler için de bir disiplin haline gelebilmiştir. Yine Keralalılık ve Tamillik gibi gayri resmi kurumlarm da Dravidanadu gibi çerçevelerle ortak gündem geçişkenliğine de şahit olunabilmektedir. Sonuç olarak Hindistan siyaseti, resmi kurumlar gibi gayri resmi kurumlar açısından da dizayn tartışmalarının öneminin artabileceğinin sinyallerini ortaya koymaktadır. 


\title{
EXTENDED ABSTRACT
}

\section{The Change of Indian Politics from a New Institutionalist Perspective}

\author{
Hayati Ünlü \\ Şırnak University
}

Global politics has been in a transition period in terms of both domestic and foreign policies. This transition period also has brought about great sociopolitical change processes. This process of change has accelerated further due to the Covid-19 pandemic. The masses faced economic crisis on the one hand and health and humanitarian crises on the one hand, and massive mass protests and demands have threatened state administrations. The most important political tools used against these rising sociological mobilizations have been institutions. Institutions' rule-setting, behavior-shaping and result-influencing features have enabled them to be the first organizations that come to mind in ensuring order and stability. On the other hand, this power of institutions has been able to use by policy makers in managing political processes. In terms of both controlling the rising mobilizations and using the mobilizations to their interests, policy makers have been able to benefit from the functions of the institutions. In particular, the capacities of political institutions have been able to provide an advantage in political processes due to their functions. In addition to the power of institutions, institutions have existed in politics not only as formal institutions but as informal institutions. In this respect, policy makers have similarly been able to benefit from the functions of not only formal institutions but also informal institutions. This informal capacity of institutions has been of great importance in shaping political processes in this direction and has been able to use by political elites from socio-political change processes. In this context, the role of informal institutions such as ideas and ideologies in the change of the political history of countries can not be denied. In this study, the change in Indian politics has been discussed through these informal institutions.

In the post-independence period of India, the actor that played the most important role in the country's politics was the Congress Party. The National Congress Movement, which was at the center of the independence mo- 
vement and directs the movement, transformed into a political party after independence and both went through an institutionalization process and managed the country's politics. When the role of the party in the independence process combined with Nehru's charisma and leadership, the Congress Party was able to establish a great hegemony in the country's politics. As a matter of fact, Rajni Kothari has named the hegemony in question as "Congress System". The Congress Party, which gave its name to the system, became the dominant party of the political system in a way that includes all institutions of the state. In this direction, the Congress Party used all formal institutions in the country for a stronger and stable administration. Informal institutions, which were important for all political processes in the country, from the legislature to the executive and from the judiciary to economic institutions, operated under the control of the Congress. With this power, the Congress Party hosted all different interests in the country's politics and had a political, social and ideological coalition function. On the other hand, in order to maintain its power, the Congress Party similarly controlled not only formal institutions but also informal institutions. It is still possible to find traces of the patronage system established by the Congress Party in the country. In addition, the most important informal institution used by the Congress Party was secularism and through secularism, the party was able to ensure that all different identities living in the country could live together. Although different secular approaches existed within the party, secularism was the most strategic tool of the Congress Party in building national identity. The fall of the Congress has emerged with the decrease of confidence in the idea of secularism and today, it is argued whether a possible rise of the Congress will be realized thanks to the need for secular politics.

The collapse of the Congress System and the incremental rise of BJP politics in the country have developed simultaneously. The BJP is today the foremost political party in Indian politics and these days, it has been discussed whether the "BJP System" emerged after the 2019 elections. This situation has developed in relation not only to the end of the confidence in the Congress System, but also to the rising Hindutva politics. Hindutva politics, whose roots date back to the first quarter of the 1900s, has gained more strength in the 1970s and is now at the center of Indian politics. Hindutva politics, whose founding father was Savarkar, has gradually become a rule, especially with the 1992 Ayodhya Events and the Gujarat Events in 2002, 
and shaped the behavior of Indian citizens, primarily Hindu voters. In this way, the idea of Hindutva has become one of the most strategic weapons of the BJP administration as an informal institution and become an informal Pan-Indian institution for a Pan-Indian hegemony. In addition, the informal institutional capacity of the Hindutva idea has given the BJP the control of many formal institutions in the country. However, the difference between Hindutva and secularism is related to its exclusionary capacity. In this respect, Hindutva, which excludes many groups in the country, particularly Muslims, has developed as a negative informal institution, not a positive informal institution contrary to secularism.

Although the Hindutva idea has had a hegemonic character as an informal institution, its negative function has led to the emergence of counterhegemonic informal institutions. These counter-hegemonic informal institutions rising through identity politics, linguistic nationalism or regional nationalism are of great importance to understand both the changing Indian politics and the future of the BJP system. This informal challenge that emerged in the context of the revival of secularism at the center of the country's politics or the rise of Ambedkarism centered on Dalit politics has been able to mobilize on a regional scale as Hilsa in West Bengal, Keralite in Kerala, and Dravidanadu in Tamil Nadu. This ongoing struggle and competition between informal institutions has actually emerged with the strategies of the $\mathrm{BJP}$, which wants to increase its power in regions where its social base is weak, and the responses of regional elites who want to respond to these strategies. This informal struggle and competition will determine the future of Indian politics. As a result, the change in Indian politics has been analyzed through the hegemonic rise of these informal institutions.

\section{Kaynakça / References}

Anderson, S. (2012). Caste dominance in Rural India: Cause and effect. https://www.ideasforindia.in/topics/governance/castedominance-in-ruralindia-cause-and-effect.html adresinden erişilmiştir.

Balasubramanian, M. (1980). Nehru: A study in secularism. Uppal.

Berman, S. (1998).The social democratic moment: Ideas and politics in the making of Interwar Europe. Harvard University Press.

Berman, S. (2013). Ideational theorizing in the social sciences since 'policy paradigms, social learning and the state'. Governance, 26(2), 217-237. 
Brinks, D. (2003). Informal institutions and the rule of law: The judicial response to state killings in Buenos Aires and Sao Paulo in the 1990s. Comparative Politics, 36(1), 1-19.

Chitkara, M. G. (1997). Hindutva. New Delhi: APH Publishing.

Colignon, R. A. ve Chikako U. (2003). Amakudari: The hidden fabric of Japans economy. Ithaca: Cornell University Press.

Collins, K. (2002). Clans, pacts and politics in Central Asia. Journal of Democracy 13 (3), $137-52$.

Curran, J.A. (1950). The RSS: Militant Hinduism. Far Eastern Survey, 19(10), $93-98$

Della Porta, D.ve Alberto V. (1999). Corrupt exchanges: Actors, resources, and mechanisms ofpolitical corruption. New York: Aldine de Gruyter.

Devare, A. (2011). History and the making of a Modern Hindu Self, Routledge.

DFID (2010). Building peaceful states and societies. A DFID Practice Paper. London:

Department for International Development.

Do Not Need Lesson On Food Habits From Delhi, Nagpur: Kerala CM Pinarayi Vijayan. (28.05.2017.). Indian Express.

Dravidanadu Demand Revives On Twitter, After Centre's Ban On Cattle Slaughter. (30.05.2017). Newsd. https://newsd.in/dravidanadu-demand-revivestwitterafter-centres-ban-cattle-slaughter/ adresinden erişilmiştir.

Gafoor, A. ve Noorani, A. M. (2002). Savarkar and Hindutva: The GodseConnection. LeftWord Books.

Giddens,A. (1984). The constitution of society: Outline of the theory of structuration. Berkeley: University of California Press.

Gokhale, J. (1993). From concessions to confrontation: The politics of an India Untouchable Community. Bombay: Popular Prakashan.

Hankla, C.R. (2008). Parties and patronage: An analysis of trade and industrial policy in India. Comparative Politics, 41(1), 41-60.

Hoveyda, A. (2011). Indian Government and politics. New Delhi: Pearson.

How Slaughter Ban Revived the Demand for \#DravidaNadu. (30.05.2017). Quint. https://www.thequint.com/news/india/how-slaughter-ban-revived-thedemandfor-dravida-nadu. adresinden erişilmiştir.

Indian Constitution. (1949). http://egazette.nic.in/writereaddata/1949/e-2358-19490000-109779.pdf (11.02.2021).

Indian PM Modi Mocked Over Kerala-Somalia Comparison. (11.05.2016). BBC. https://www.bbc.com/news/world-asia-india-36264001 adresinden erişilmiştir. 
Iyer, A. (30.04.2017,). Modi govt contemptuous of Tamil Nadu, imposing Hindi: DMK's Stalin. Hindustan Times, https://www.hindustantimes.com/indianews/modi-govt-contemptuous-oftamil-nadu-imposing-hindi-dmk-sstalin/storyWRI/K7qIMubfv7Z4KmluQJ.html adresinden erişilmiştir.

Jaffrelot, C. (1999). The Hindu nationalist movement in India. The Journal of Asian Studies. 58(2).

Jaffrelot, C. (2010). Religion, caste, and politics in India. New Delhi:Primus Books. Joglekar, J. (2006). Veer Savarkar Father of Hindu Nationalism. New Delhi:Lulu.com.

Jütting J., Drechsler D., Bartsch, S. ve de Soysa, I. (2007). Informal institutions: How social norms help or hinder development. Paris: OECD. http://browse.oecdbookshop.org/oecd/pdfs/product/4107101e.pdf _adresinden erişilmiştir.

Kothari, R. (1964). The Congress 'System' in India. Asian Survey, 4(12), 1161-1173.

Kumar, A. (2016). Growth of secularism in the Indian Society. National Journal of Advanced Research, 2(3).

Kundu, I. (2018). Hindutva Vs Hilsa in West Bengal: How Mamata Banerjee Will Counter Amit Shah's Saffron Surge, Dailyo. https://www.dailyo.in/politics/mamata-banerjee-tmc-bjp-amit-shahwestbengal/story/1/26310.html adresinden erişilmiştir.

Langston, Joy. 2003. The formal bases of informal power: Mexico. Paper presented at the conference Informal Institutions and Politics in Latin America, Kellogg Institute for International Studies, University of Notre Dame, April 24-25.

Leftwich, A. ve Sen, K. (2010). Beyond institutions: Institutions and organizations in the politics and economics of poverty reduction - Thematic synthesis of research evidence. DFID-funded Research Programme Consortium on Improving Institutions for Pro-Poor Growth (IPPG). Manchester: University of Manchester. http://www.ippg.org.uk/8933 Beyond\%20Institutions.final\%20(1).pdf adresinden erişilmiştir.

Levitsky, S. (2001). An "organized disorganization": Informal organization and the persistence of local party structures in Argentine Peronism. Journal of Latin American Studies 33 (1), 29-68.

Lowndes V. ve Roberts M. (2013). Why institutions matter: The new institutionalism in political science. London: Red Globe Press.

Mathew, Joseph (1986). Ideology, protest, and social mobility : Case Study of Mahars $\mathcal{E}$ Pulayas. New Delhi:Inter-India Publications, 
Migdal, J. S. (2001). State in society: Studying how states and societies transform and constitute each other. New York: Cambridge University Press.

North, D.C. (1990). Institutions, institutional change, and economic performance. New York: Cambridge University Press.

O'Donnell, G. (1994). Delegative democracy. Journal of Democracy, 5(1), 55-69.

Omvedt, G. (1994). Dalits and the democratic revolution: Dr Ambedkar and the Dalit Movement in Colonial India. Sage, New Delhi.

Pandian, J. (1987). Caste, nationalism and ethnicity: An interpretation of Tamil Cultural History and Social Order. Bombay: Popular Prakashan,

Panigrahi, D. N ve Gandhi, I. (1985). Indira Gandhi: An apostle of national integration. Vikas.

Pantham, T. (1997). Indian secularism and its critics: Some reflections. The Review of Politics. 59(3), 523-540.

Parvathy, A. A.(2003). Hindutva, ideology, and politics. Deep \& Deep Publications.

Pisharoty, S. B. (05.08.2018). Both the BJP and the Trinamool Congress Are Stirring the Communal Pot in Assam. The Wire, , https://thewire.in/politics/bjp-tmc-nrcassam-communalism adresinden erişilmiştir.

Polanyi, K. (2001). The great transformation: The political and economic origins of our time. 2nd ed. Foreword by J. E. Stiglitz; introduction by Fred Block. Boston: Beacon Press.

Purohit, B. R. (1965). Hindu Revivalism and Indian nationalism. Sathi Prakashan.

Sarvarkar, V.D. (2003). Excerpts from Hindutva.ed. Chakrabarty B. Communal Identity in India: Its Construction and Articulation in the Twentieth Century.New Delhi: Oxford University Press.

Scroll.in. (2016). \#PoMoneModi: Go away, sonny, say Malayalis As Prime Minister Compares Kerala To Somalia.https://scroll.in/article/807927/pomonemodi-go-awaysonny-say-malayalis-asprime-minister-compares-kerala-to-somalia adresinden erişilmiştir.

Sen, A. (1993). The threats to secular India. Social Scientist, 21(3/4), 5-23.

Sen, A. (2004). Democracy and secularism in India. Basu, K. (ed.). India's Emerging Economy. MIT Press.

Seth, S. (2006). The critique of renunciation: Bal Gangadhar Tilak's Hindu nationalism. PostColonial Studies, 9(2).

Sharma, J. (2007). Terrifying vision: M. S. Golwalkar, the RSS, and India. Penguin Books. 
Stalin Hits Out Against Move to Dub or Carry Hindi Subtitles in Regional Films. (30.05.2017). News 18. https://www.news18.com/news/politics/stalin-hitoutagainst-move-to-dub-or-carry-hindi-subtitles-in-regional-films-1387857.html adresinden erişilmiştir.

Suda, J. P. (1969). The Indian National movement. Jai Prakash Nath.

Swaroop, S.S. (2017). A Critique of 'Hind Swaraj' and 'Hindutva', ournal of Politics and Governance. 6(1).

Tandon, A. ve Singh V. K. (2013). Impact of Mahatma Gandhi's concepts on mental health: Reflections. Indian Journal of Psychiatry, 55(Suppl 2).

Trivedi, P. (2017). Architect of a philosophy. Kanpur Graphics, Kanpur.

Unsworth, S. (2010). An upside down view of governance. Brighton: IDS. http://www2.ids.ac.uk/gdr/cfs/pdfs/AnUpsidedownViewofGovernance.pdf adresinden erişilmiştir.

Upadhyaya, P.C. (1992). The Politics of Indian secularism. Modern Asian Studies, 26(4), 815-853.

Wilson, R. (1997). Human rights, culture \& context. Anthropological Perspectives. London: Pluto Press.

\section{Kaynakça Bilgisi / Citation Information}

Ünlü, H. (2021). Yeni kurumsalcı perspektiften Hindistan siyasetinin değişimi. OPUS-Uluslararası Toplum Araştırmaları Dergisi, 17(34), 1455-1486. DOI: 10.26466/opus.796323 